\title{
ВУЗОВСКОЕ СЕЙСМИЧЕСКОЕ ОБРАЗОВАНИЕ: ПРОБЛЕМЫ И ОПЫТ ИХ РЕШЕНИЯ
}

Бондарев В.И., Крылатков С.М.

(Уральский государственный горный университет (УГГУ))

В докладе обсуждается содержание и проблемы преподавания важнейшего метода разведки в геофизическом вузовском образовании. Предлагается оригинальная точка зрения на роль и значение тралиционных для сейсморазведки разделов курса. Комментируется содержание авторского курса сейсмической разведки. Наиболее подробно анализируется содержание третъей части курса, посвященной изложению вопросов обработки и интерпретации данньх сейсморазведочных работ. Обсуждается содержание и проблемы специализированной подготовки выпускников вузов в области сейсмической разведки. Излагается накопленный опыт решения таких проблем в УГТУ.

В настоящее время роль сейсморазведочных работ в комплексе геологоразведочных работ на нефть и газ стала весьма значительной и продолжает непрерывно возрастать. Существенно изменилась и усложнилась технология ведения полевых работ, появилось принципиально новое поколение сейсморазведочной регистрирующей аппаратуры. Особенно значителен прогресс в методиках и средствах обработки и интерпретации получаемой сейсмической информации. Теория процессов получения и обработки различных интерпретационньх параметров сейсмической записи (атрибутов) существенно расширилась и усложнилась.

Между тем, в структуре стандартов высшего геофизического образования временные пропорции между методами разведочной геофизики остаются прежними и мало разлнчаются. Отсюда и возникает проблема, как уложить в существующие временные рамки стандартного вузовского образования тот широкий круг новых знаний, которые возникли в последнее время в сейсмической разведке?

Сегодня базовый курс сейсморазведки, читаемый в большинстве вузов России состоит, как правило, из трех частей: 1.Физико-математические и геологические основы сейсморазведки; 2.Методы, аппаратура и технология сейсморазведочньгх работ; 3.Обработка и интерпретация данньх сейсморазведочных работ.

Одним из важнейшпх элементов вузовского сейсморазведочного образования являются учебники и учебные пособия по сейсморазведке, используемые студентами для обучения. В России в настояшее время существует лишь очень небольшое число учебников и учебных пособий (Бондарев В.И,, Урупов А.К., Кузнецов В.И., Боганик Г.Н.), в которых с позиций сегодняшнего дня излагаются все или часть разделов сейсмической разведки.

Одним из последних изданий является учебник "Сейсморазведка" одного из авторов данного сообщения. Он состоит из трех частей, соответствуюших базовым разделам основного курса дисциплины. Особенно спорным в кругу вузовской общественности является содержание второй и третьей части курса. При этом наибольшие разногласия возникают по третьему разделу курса, посвященному алгоритмам и технологиям преобразования сейсми- ческих данньх с целью получения геологических результатов

Автор обсуждаемого учебника в качестве основы для создакия третъей части учебного курса сейсморазведки взял за основу две фундаментальные монографии известных западных специалистов Oz. Yilmas (Seismic Data Analysis) и A. Brown (Interpretation of Three-Dimensional Seismic Data).

Содержание этой пасти курса включает: общие вопросы обработки и огисание содержания основных процедур интерпретации данных сейсмической разведки; получение атрибутньх изображений геологической среды и общие принципы геологической интерпретации данных сейсмической разведки (интерпретачионная обработка данных сейсморазведкu); примеры и перспективы применения сейсморазведки при решения различных прикладных задач. В докладе обсуждаются проблемы именно этой части курса, возникшие при построении базового учебного курса.

Углубленное современное сейсморазведочное образование молодого специалиста в вузе может быть осуществлено только при условии, что в дополнение к базовому курсу сейсмической разведки вуз сможет осуществить и специализированное обучение ключевым разделам курса на завершающем этапе подготовки инженера-сейсморазведчика. Такая углубленная подготовка осуществляется в ряде вузов России. Она обычно включает в себя как теоретическую часть, так и хорошую практическую подготовку. При этом полноценная практическая подготовка студентов, в силу сложности всего технологического цикла сейсморазведодных работ, может быть осуществлена только при использовании производственной базы современных сейсморазведочных предтриятий.

В докладе излагается положительный опыт такой специализированной сейсморазведочной подготовки, накопленњый в Уральском государственном горном университете и реализуемый в тесном сотрудничестве и при поддержке ведущих сервисньх геофизических компаний ОАО "Хантымансийскгеофизика", ОАО "Сибнефтегеофизика"и др.

\section{ЛИТЕРАТУРА}

Бондарев В.И., 2002, Анализ данных сейсморазведки. Екатеринбург: Изд-во УГГГА, $212 \mathrm{c}$.

Бондарев В.И., 2003, Основы сейсморазведки. Екатеринбург: Изд-во УГГГА, 334c.

Кузнецов В.И., 2004, Элементы объемной сейсморазведки. Тюменъ: Изд-во Тюмень, 272с.

Урупов А. К., 2004, Основы трехмерной сейсморазведки. Москва: Изд-во Нефть и газ, 584c.

Бондарев В.И.,2006, Сейсморазведка. Екатеринбург: Изд-во УГГУ, Т.1-136c, T.2-224c., T.3-336c.

Боганик Г.Н., Гурвич И.И. 2006, Сейсморазведка, Тверь, Изд-во AИС, $756 \mathrm{c}$. 